\title{
Encapsulation of L-5-methyltetrahydrofolate by electrospraying for food applications
}

Ložnjak Švarc, Petra; García Moreno, Pedro Jesús; Mendes, Ana Carina Loureiro; Fallahasghari, Elnaz Z.; Jakobsen, Jette

Published in:

Journal of Food Engineering

Link to article, DOI:

10.1016/j.jfoodeng.2019.109901

Publication date:

2020

Document Version

Peer reviewed version

Link back to DTU Orbit

Citation (APA):

Ložnjak Švarc, P., García Moreno, P. J., Mendes, A. C. L., Fallahasghari, E. Z., \& Jakobsen, J. (2020).

Encapsulation of L-5-methyltetrahydrofolate by electrospraying for food applications. Journal of Food

Engineering, 277, [109901]. https://doi.org/10.1016/j.jfoodeng.2019.109901

\section{General rights}

Copyright and moral rights for the publications made accessible in the public portal are retained by the authors and/or other copyright owners and it is a condition of accessing publications that users recognise and abide by the legal requirements associated with these rights.

- Users may download and print one copy of any publication from the public portal for the purpose of private study or research.

- You may not further distribute the material or use it for any profit-making activity or commercial gain

- You may freely distribute the URL identifying the publication in the public portal 


\section{Journal Pre-proof}

Encapsulation of L-5-methyltetrahydrofolate by electrospraying for food applications

Petra Ložnjak Švarc, Pedro J. García-Moreno, Ana C. Mendes, Elnaz Z.

Fallahasghari, Jette Jakobsen

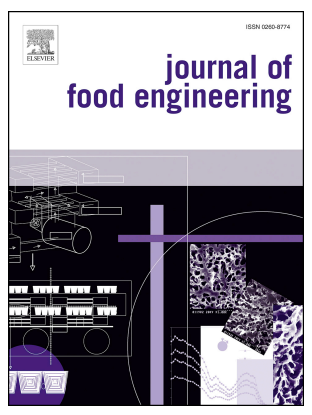

PII:

S0260-8774(19)30544-8

DOI:

https://doi.org/10.1016/j.jfoodeng.2019.109901

Reference:

JFOE 109901

To appear in: Journal of Food Engineering

Received Date: 28 October 2019

Revised Date: 12 December 2019

Accepted Date: 28 December 2019

Please cite this article as: Ložnjak Švarc, P., García-Moreno, P.J., Mendes, A.C., Fallahasghari, E.Z., Jakobsen, J., Encapsulation of L-5-methyltetrahydrofolate by electrospraying for food applications, Journal of Food Engineering (2020), doi: https://doi.org/10.1016/j.jfoodeng.2019.109901.

This is a PDF file of an article that has undergone enhancements after acceptance, such as the addition of a cover page and metadata, and formatting for readability, but it is not yet the definitive version of record. This version will undergo additional copyediting, typesetting and review before it is published in its final form, but we are providing this version to give early visibility of the article. Please note that, during the production process, errors may be discovered which could affect the content, and all legal disclaimers that apply to the journal pertain.

(C) 2019 Published by Elsevier Ltd. 


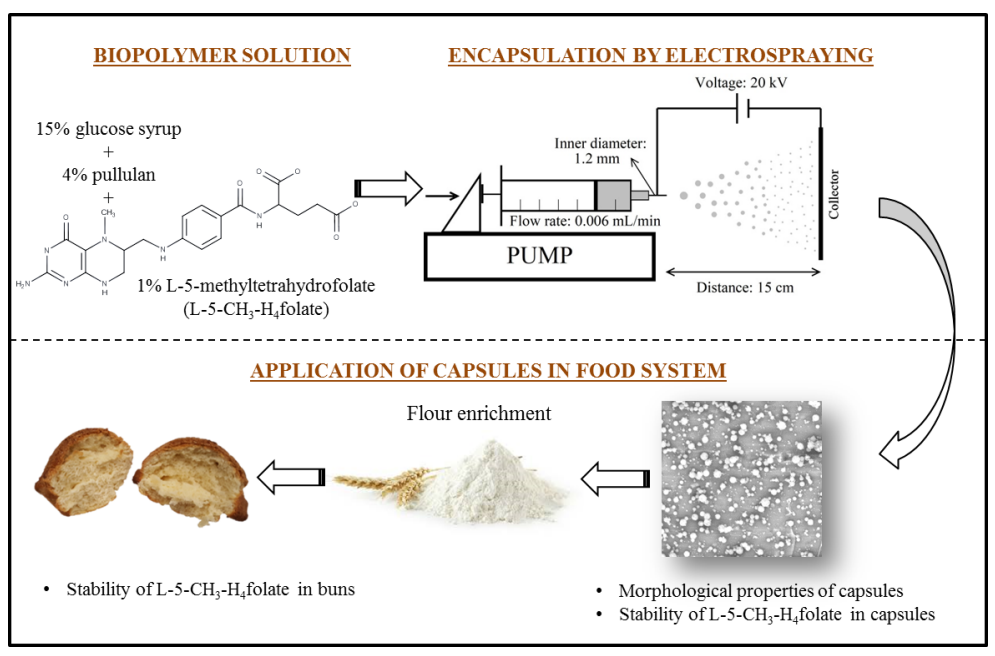


Title:

2 Encapsulation of L-5-methyltetrahydrofolate by electrospraying for food applications

\section{Authors:}

4 Petra LOŽNJAK ŠVARC ${ }^{\mathrm{a} *}$, Pedro J. GARCÍA-MORENO ${ }^{\mathrm{a}, \mathrm{b}}$, Ana C. MENDES ${ }^{\mathrm{c}}$, Elnaz Z. 5 FALLAHASGHARI ${ }^{\mathrm{a}, \mathrm{c}}$, Jette JAKOBSEN ${ }^{\mathrm{a}}$

$6{ }^{a}$ Research Group for Bioactives - Analysis and Application, National Food Institute, Technical

7 University of Denmark, Kemitorvet, 2800 Kgs. Lyngby, Denmark

$8{ }^{\mathrm{b}}$ Department of Chemical Engineering, University of Granada, Avenida de la Fuente Nueva S/N

$9 \quad$ P.C 18071 Granada 18071, Spain

$10{ }^{c}$ Research Group for Nano-Bio Science, National Food Institute, Technical University of Denmark,

112800 Kgs. Lyngby, Denmark

12 *Corresponding author: Petra Ložnjak Švarc, Research Group for Bioactives - Analysis and

13 Application, National Food Institute, Technical University of Denmark, Kemitorvet, $2800 \mathrm{Kgs.}$

14 Lyngby, Denmark, Telephone: + 45 93518869, E-mail: petlon@food.dtu.dk

\section{Abstract:}

16 Biologically active natural folate form L-5-methyltetrahydrofolate is less stable than synthetic folate

17 form folic acid commonly used for food fortification. The production of electrosprayed capsules 18 using a combination of carbohydrates such as glucose syrup and pullulan was investigated to 19 provide higher stability of L-5-methyltetrahydrofolate in food products. Additionally, the protective

20 effect of ascorbic acid, if added to the biopolymer solution for capsules production was 21 investigated. During the production of electrosprayed capsules containing L-5- 
methyltetrahydrofolate, both with and without ascorbic acid, the recovery of folate was $>97 \%$. During storage at $22^{\circ} \mathrm{C}$ for 21 days, the electrosprayed capsules (with or without ascorbic acid) showed significantly higher folate recovery compared to free L-5-methyltetrahydrofolate (91\% vs. $61 \%, \mathrm{p} \leq 0.05)$. In buns baked with all-purpose flour fortified with the free form or the electrosprayed capsules, which were stored at $22^{\circ} \mathrm{C}$ for 9 days, no significant difference was shown for the retention of the L-5-methyltetrahydrofolate.

\section{Keywords:}

L-5-Methyltetrahydrofolic acid; Fortification; LC-MS/MS; Food; Stability; Retention

\section{Abbreviations:}

NTDs, Neural tube defects; 5- $\mathrm{CH}_{3}-\mathrm{H}_{4}$ folate, 5-methyltetrahydrofolate, natural form; $\mathrm{L}-5-\mathrm{CH}_{3}-$ $\mathrm{H}_{4}$ folate, L-5-methyltetrahydrofolate, synthetic form; Asc, Ascorbic acid; Capsules - Asc, Capsules without ascorbic acid; Capsules + Asc, Capsules containing ascorbic acid

\section{Introduction}

5-methyltetrahydrofolate $\left(5-\mathrm{CH}_{3}-\mathrm{H}_{4}\right.$ folate $)$ is the predominant naturally occurring form of folate or vitamin $\mathrm{B}_{9}$ group. This group of biologically active compounds plays an important role in human health as it is vital for one-carbon transfer and normal cellular functions such as methylation and regeneration of DNA, where 5- $\mathrm{CH}_{3}-\mathrm{H}_{4}$ folate is involved in biologic processes (Scaglione and Panzavolta, 2014). Adequate folate intake prevents the development of neural tube defects (NTDs), anemia, cardiovascular diseases, cancer, and degenerative cognitive diseases (Bailey et al., 2015). Even though naturally occurring folate is widely distributed in food, its intake is often insufficient (Obeid et al., 2016). More than 260,000 pregnancies worldwide are estimated to be affected by NTDs (Garrett and Bailey, 2018), whereas $44 \%$ of the pregnancies are unintended, which also 
contributes to the birth defects risk as folate plays a significant role in the first months after conception (Bearak et al., 2018). In order to reduce the prevalence of mentioned diseases and to improve the nutritional quality of the food supply, FDA established mandatory fortification of cereal-grain products among the others; flour, bread, macaroni products in the USA and Canada by folic acid, a synthetic and the most stable folate form (Food and Drug Administration, 1996). In the following years, 81 countries mandated fortification of wheat flour, maize flour, or rice by folic acid, which resulted in a significant reduction of NTDs. This led to the conclusion that food fortification by folic acid should be part of most national public health strategies (Garrett and Bailey, 2018). However, folic acid as a synthetic folate form has to pass additional metabolic processes in order to convert to biologically active folate form $5-\mathrm{CH}_{3}-\mathrm{H}_{4}$ folate. Upon the chronic intake of synthetic form ( $>200 \mu \mathrm{g} /$ day), un-metabolized folic acid is circulating in the body, which results in the occurrence of adverse health effects (Stolzenberg-Solomon et al., 2006) and masking of vitamin $B_{12}$ deficiency (Green et al., 2013). The use of supplements and voluntary fortification of food products with folic acid are recommended in the European Union, but not mandatory (European Union, 2002, 2006). There is a concern about the occurrence of adverse health effects, which presumably resulted in a decrease of voluntary fortification by folic acid in some countries such as Spain (Samaniego-Vaesken et al., 2017). A fortification of $150 \mu \mathrm{g}$ folic acid per $100 \mathrm{~g}$ of food showed to be effective in the reduction of the prevalence of NTDs and the increase in blood folate concentrations in the USA and Canada (Berry et al., 2010).

L-5- $\mathrm{CH}_{3}-\mathrm{H}_{4}$ folate, Metafolin, a synthetic form of natural $5-\mathrm{CH}_{3}-\mathrm{H}_{4}$ folate is a biologically active folate form that does not have to undergo additional metabolic conversion, it does not mask $\mathrm{B}_{12}$ deficiency as folic acid does and it is more suitable for food fortification (Obeid et al., 2013; Pietrzik et al., 2010). However, $\mathrm{L}-5-\mathrm{CH}_{3}-\mathrm{H}_{4}$ folate is very unstable under various environmental conditions such as changes in $\mathrm{pH}$, temperature, oxygen, or light exposure, which makes its 
68 incorporation to food systems challenging (Liu et al., 2012). Green et al. (2013) studied the bioavailability of encapsulated $\mathrm{L}-5-\mathrm{CH}_{3}-\mathrm{H}_{4}$ folate and folic acid from fortified wheat rolls and found no differences in bioavailability, indicating that replacing folic acid by encapsulated $\mathrm{L}-5-\mathrm{CH}_{3}-$ $\mathrm{H}_{4}$ folate would reduce concerns regarding the masking of $\mathrm{B}_{12}$ deficiency and adverse health effects of chronic consumption of folic acid.

Due to its low stability, the protection of $\mathrm{L}-5-\mathrm{CH}_{3}-\mathrm{H}_{4}$ folate in the food system and gastrointestinal tract is desirable. Encapsulation has been proposed as a new technology for packing materials in the form of micro- or nanostructures by entrapping bioactive compounds and protecting them by another substance in order to increase the stability of bioactive compounds during processing and storage (Dias et al., 2015). Spray-drying is the most commonly used encapsulation technique. However, despite the short processing time, spray-drying can cause deterioration of labile ingredients such as folate due to the contact of the droplet/particle with air at high temperature (100$220{ }^{\circ} \mathrm{C}$ ) in the drying chamber (Jacobsen et al., 2018). Electrospray has shown to be a good

81 alternative to spray-drying since no high temperatures are used during the process (García-Moreno et al., 2018a). Its relevance for the encapsulation of thermally sensitive bioactive compounds is supported by recent research based on the increase of the productivity of the process (Busolo et al., 2019). This technique is based on the use of a high voltage electric field to generate dry polymeric particles. In electrospray, the jet ejected from the Taylor cone breaks down into fine charged droplets from where the solvent evaporates during the flight to a grounder collector, and the result is concentrations of $\mathrm{L}-5-\mathrm{CH}_{3}-\mathrm{H}_{4}$ folate in the final product after the encapsulation and the one initially added to the dry mixture, ranged from 70 to $91 \%$. 
The properties of biopolymer solutions (e.g., viscosity, surface tension, conductivity), as well as of the solvent (e.g., vapor pressure), highly affect electrospraying process such as stability of Taylor cone and morphology of the capsules (Jacobsen et al., 2018; Tapia-Hernández et al., 2017). Pectin and alginate are often used for encapsulation of folic acid due to the low cost and biocompatibility, even though coating materials such as stearate, skimmed milk powder, and modified starch have also been used (Alborzi et al., 2013; Kitts and Liu, 2015). In this study, glucose syrup was used as the main carbohydrate due to its ability to form capsules of appropriate morphology by electrospraying, whereas pullulan was used to stabilize the electrospraying process (García-Moreno et al., 2018b; Hermund et al., 2019). Glucose syrup is a common and low-cost coating material used 101 for the encapsulation of bioactive compounds for application in food (García-Moreno et al., 2018b).

102 Furthermore, glucose syrup-electrosprayed capsules have lower oxygen permeability when 103 compared to higher molecular weight carbohydrates such as dextran (Boerekamp et al., 2019). The latter is of special importance for the protection of oxidative unstable bioactives such as $\mathrm{L}_{-}-\mathrm{CH}_{3}-$ $\mathrm{H}_{4}$ folate. Besides, the protective effect of ascorbic acid (Asc) against oxidation was also examined, as L-5- $\mathrm{CH}_{3}-\mathrm{H}_{4}$ folate is instable under various environmental conditions (Kitts and Liu, 2015).

To the best of our knowledge, the encapsulation of $\mathrm{L}-5-\mathrm{CH}_{3}-\mathrm{H}_{4}$ folate by electrospray, that could provide even higher protection of the bioactive compound than spray-drying, remains to be investigated. Electrospraying is performed at room temperature, which is convenient for 110 encapsulation of thermally sensitive compounds such as $\mathrm{L}-5-\mathrm{CH}_{3}-\mathrm{H}_{4}$ folate. Furthermore, the 111 reduced capsule size compared to spray-drying enables easier incorporation in a food matrix (Kitts 112 and Liu, 2015). As the main ingredient in bakery products being already used for fortification by 113 folic acid, all-purpose flour seems to be a good candidate to be fortified with 5- $\mathrm{CH}_{3}-\mathrm{H}_{4}$ folate. Due 114 to the costliness of the pure 5- $\mathrm{CH}_{3}-\mathrm{H}_{4}$ folate, the synthetic Metafolin form of $\mathrm{L}-5-\mathrm{CH}_{3}-\mathrm{H}_{4}$ folate was 115 used in this study as it was proposed by previous studies (Liu et al., 2015, 2013). 
116 The study aimed to investigate the encapsulation of $\mathrm{L}-5-\mathrm{CH}_{3}-\mathrm{H}_{4}$ folate by electrospraying using a 117 combination of carbohydrates, such as glucose syrup and pullulan, as coating materials. The study 118 included optimization of the electrospraying process and testing the oxidative stability of the 119 capsules loaded with $\mathrm{L}-5-\mathrm{CH}_{3}-\mathrm{H}_{4}$ folate during 21 days of storage. In addition, the protecting effect 120 of encapsulation during processing was tested by studying the fortification of buns produced with 121 all-purpose flour containing electrosprayed capsules loaded with $\mathrm{L}-5-\mathrm{CH}_{3}-\mathrm{H}_{4}$ folate.

\section{Materials and methods}

\subsection{Materials}

Glucose syrup (DE38, C*Dry 1934) was kindly provided by Cargill Germany GmbH (Krefeld, Germany). Pullulan (molecular weight $=200,000 \mathrm{Da}$ ) and Tween-20 (polyethylene glycol sorbitan monolaurate) were provided by Hayashibara Co., Ltd. (Okayama, Japan) and Sigma-Aldrich

127 (Steinheim, Germany), respectively. L-5-Methyltetrahydrofolic acid (L-5-CH $3-\mathrm{H} 4$ folate, (6S)-5methyltetrahydrofolic acid, calcium salt, Metafolin) was provided from Merck \& Cie (Schaffhausen, Switzerland). All-purpose flour and granulated sugar (Vores bagværk), salt, instant dry yeast (Malteserkors), eggs (Barkholt), and sunflower oil were bought from the local 131 supermarket (Copenhagen, Denmark).

\subsection{Optimization of biopolymer solutions for electrospraying process}

133 The main compounds of the electrospraying solution, such as glucose syrup (15\%) and pullulan 134 (4\%), were selected based on previous work (García-Moreno et al., 2018b). The experiments 135 involved in the optimization of the electrospraying process included the addition of $1 \%$ Asc, $1 \%$ 136 Tween-20 surfactant, and the use of 3-5 Microfluidizer passes (M110L Microfluidics, Newton, MA, 137 USA). The addition of Asc to the electrospraying solution was carried out to test its effect on the 138 stability of $\mathrm{L}-5-\mathrm{CH}_{3}-\mathrm{H}_{4}$ folate in a further study during the electrospraying process, storage, and 
139 processing of the capsules. Tween-20 addition, which reduces the surface tension of the biopolymer 140 solution, and passing the biopolymer solution through a high-pressure homogenizer (e.g., 141 Microfluidizer), which breaks biopolymer chains reducing polymer entanglements, were also 142 carried out in order to evaluate their influence on electrosprayability.

143 Briefly, pullulan and glucose syrup were dissolved in distilled water under constant stirring (700 $144 \mathrm{rpm}$ ) for $30 \mathrm{~min}$ at room temperature. Asc was added, dissolved, and further homogenized in a 145 Microfluidizer (M110L Microfluidics, Newton, MA, USA) equipped with a ceramic interaction 146 chamber (CIXC, F20Y, internal dimension $75 \mu \mathrm{m}$ ). The solutions for electrospraying were 147 homogenized at a pressure of 9,000 psi, with 3 passes, whereas 5 passes were also tested. In order to 148 investigate the effect of the surfactant in the process of electrospraying, $1 \%$ Tween-20 was added to 149 the solution before and after homogenization. $\mathrm{L}-5-\mathrm{CH}_{3}-\mathrm{H}_{4}$ folate was included in the optimization 150 process after the homogenization of the solutions produced in optimal conditions. Solution with L$1515-\mathrm{CH}_{3}-\mathrm{H}_{4}$ folate was stored in a brown glass vial, atmospheric oxygen was substituted by nitrogen, 152 and the vial was slowly turned up and down by hand for 3 min until L-5- $\mathrm{CH}_{3}-\mathrm{H}_{4}$ folate was 153 completely dissolved. The resulting solutions for electrospraying contained $1 \%$ wt $\mathrm{L}_{-} 5-\mathrm{CH}_{3}-$ $154 \mathrm{H}_{4}$ folate. Two different solutions were tested: one without Asc (Capsules - Asc) and one with 1\% 155 Asc $($ Capsules + Asc) . The biopolymer solutions were prepared up to 3 days before electrospraying 156 and stored at room temperature in brown glass vials. $\mathrm{L}-5-\mathrm{CH}_{3}-\mathrm{H}_{4}$ folate was added to the solutions 157 right before the electrospraying process in order to avoid oxidation and possible light degradation. 158 All techniques and analysis including $\mathrm{L}-5-\mathrm{CH}_{3}-\mathrm{H}_{4}$ folate were performed under subdued light using 159 brown glass in order to protect photo-sensitive folates.

\subsection{Electrospraying process}


161 Electrospraying process was performed at room temperature and environmental conditions of 162 relative humidity (26-50\%). Biopolymer solutions were added to a syringe, which was placed in a 163 syringe pump (New Era Pump Systems, Inc., USA). A 16G needle (Proto Advantage, Canada) was 164 used. A high-voltage electrostatic field was supplied by a high voltage power supply (Gamma High 165 Voltage Research, USA), and applied between the spinneret and a stainless steel $15 \times 15 \mathrm{~cm}$ collector 166 plate. The system was set horizontally, where the distance between needle tip and collector was 15 $\mathrm{cm}$. In order to stabilize the Taylor cone and avoid dripping of the solution on the collector, different flow rates and voltages in the ranges of $0.001-0.007 \mathrm{~mL} / \mathrm{min}$ and $16-20 \mathrm{kV}$ were tested, respectively.

The productivity of the electrospraying process was calculated as the weight (mg) of powder collected in $1 \mathrm{~h}$, and it was used during the optimization of the process.

\subsection{Characterization of electrosprayed capsules}

\subsubsection{Morphology}

A Scanning Electron Microscopy (SEM) (Phenom-World B.V., Eindhoven, The Netherlands) was used in order to examine the morphology of the capsules produced by electrospraying. The capsules from different experiments were collected on the foil and kept in a desiccator in order to examine the effect of Asc and surfactant addition, as well as the use of different Microfluidizer passes.

178 Approximately $0.5 \mathrm{~cm}^{2}$ of aluminum sheet covered with a thin layer of electrosprayed capsules was 179 placed on carbon tape and sputter-coated with gold, 8s, $40 \mathrm{~mA}$ utilizing a Q150T Quorum Coater 180 (Quorum Technologies Ltd, East Sussex, UK). The capsule diameter distribution was determined 181 from the micrographs by using an image processing program ImageJ (National Institutes of Health). 182 Size distributions were obtained from a minimum of 100 measurements. 
184 Immediately after the electrospraying, a part of the capsules was stored in a desiccator in darkness

185 at room temperature, and the other part at $-80{ }^{\circ} \mathrm{C}$. The content of $\mathrm{L}-5-\mathrm{CH}_{3}-\mathrm{H}_{4}$ folate was quantified

186 the day the capsules were produced and after a 1-month storage at $-80{ }^{\circ} \mathrm{C}$. Furthermore, $1 \% \mathrm{~L}-5$ $187 \mathrm{CH}_{3}-\mathrm{H}_{4}$ folate in water solution was prepared and used as a control representing non-encapsulated 188 folate. It was stored at room temperature $\left(22^{\circ} \mathrm{C}\right)$ in darkness for 21 days together with fresh 189 Capsules + Asc and Capsules - Asc, to simulate storage conditions of cereal-grain products that are 190 commonly stored at room temperature. Vials $(4 \mathrm{~mL})$ contained approximately $1 \mathrm{~mL}$ of control 191 solution and $150 \mathrm{mg}$ of capsules in order to maintain a similar headspace. At days $0,3,7,14$, and 192 21, three subsamples of each sample were analyzed for the content of $\mathrm{L}-5-\mathrm{CH}_{3}-\mathrm{H}_{4}$ folate.

\subsection{Stability study in fortified buns}

\subsubsection{Flour fortification}

L-5- $\mathrm{CH}_{3}-\mathrm{H}_{4}$ folate was added, in a free form, or the encapsulated forms (Capsules - Asc, and Capsules $+A s c)$ to a small amount of flour. This small amount of the mixture was dispersed using mortar and pestle before being mixed with the rest of the flour by a commercial-grade mixer. The final concentration of $\mathrm{L}-5-\mathrm{CH}_{3}-\mathrm{H}_{4}$ folate was aimed to be $\sim 150 \mu \mathrm{g} / 100 \mathrm{~g}$ of flour. Six subsamples of each of the fortified flour were sampled for quantification of $\mathrm{L}-5-\mathrm{CH}_{3}-\mathrm{H}_{4}$ folate content, in order to ensure even distribution. Unfortified flour was also analyzed for the folate content $(n=3)$ and was used for the preparation of buns, which was necessary for the calculation of folate retention.

\subsubsection{Buns production}

$12 \mathrm{~g}$ of active dry yeast was mixed with $20 \mathrm{~g}$ of sugar and $100 \mathrm{~mL}$ of water. Yeast was mixed with one egg, $40 \mathrm{~g}$ of oil and $400 \mathrm{~g}$ of flour was added with $1 \mathrm{tsp}$ salt. The elastic dough was kneaded and separated into 15 balls, from which 12 were placed on a baking tray as presented in Supplementary online material (SOM, Fig. S1), and 3 were analyzed as the dough. Buns were 
baked at $200^{\circ} \mathrm{C}$ for 7.5 min until they were risen and golden brown. Three baking batches were carried out, representing three replicates of processing conditions, where four buns were baked in each batch. They were separated after baking to represent different storage conditions, as it is shown on Fig. 1. The buns were weighed before and after the processing, and folate content was 211 analyzed before and after the thermal procedure.

Figure 1 The design of the storage experiment in buns. It included retention study during baking (1) and stability study during storage for $0,3,6$, and 9 days (2). Three replicates were sampled at each sampling point. *indicate dough samples sampled for the calculation of the retention $(n=3)$.

The quantification of $5-\mathrm{CH}_{3}-\mathrm{H}_{4}$ folate was performed with a slightly modified version of the LCMS/MS method described in detail elsewhere (Ložnjak et al., 2019). Instead of $1 \mathrm{~g}$ of samples, 0.01 $\mathrm{g}$ of capsules were dissolved in $25 \mathrm{~mL}$ of folate extraction buffer $(50 \mathrm{mM}$ phosphate buffer, $1 \%$ Asc, $0.1 \% \beta$-mercaptoethanol, $\mathrm{pH} 6.0$ ), and diluted to the concentration of approximately 500 $\mathrm{ng} / \mathrm{mL}$. When fortified flour or buns were analyzed, $0.5 \mathrm{~g}$ of the sample was mixed with $10 \mathrm{~mL}$ of folate extraction buffer. ${ }^{13} \mathrm{C}_{5}-5-\mathrm{CH}_{3}-\mathrm{H}_{4}$ folate internal standard was added for quantification. Samples were shaken vigorously after $15 \mathrm{~min}$ and cleaned by strong anion exchange solid-phase extraction prior to detection and quantification by LC-MS/MS (Ložnjak et al., 2019).

\subsection{Recovery and retention of $5-\mathrm{CH}_{3}-\mathrm{H}_{4}$ folate}

226 Calculations of recovery and retention of $\mathrm{L}-5-\mathrm{CH}_{3}-\mathrm{H}_{4}$ folate was exemplified by $5-\mathrm{CH}_{3}-\mathrm{H}_{4}$ folate in 227 Eq. 1 and 2. The recovery of 5- $\mathrm{CH}_{3}-\mathrm{H}_{4}$ folate in capsules was calculated according to Eq. 1:

$$
\text { Recovery }(\%)=\frac{\text { concentration of } 5-\mathrm{CH}_{3}-\mathrm{H}_{4} \text { folate } \text { quantified }}{\text { concentration of } 5-\mathrm{CH}_{3}-\mathrm{H}_{4} \text { folate } \text { added }} * 100
$$


229 The retention of 5- $\mathrm{CH}_{3}-\mathrm{H}_{4}$ folate in buns was calculated according to Eq. 2 :

$$
\text { Retention }(\%)=\left(\frac{\mu g 5-\mathrm{CH}_{3}-\mathrm{H}_{4} \text { folate per } 100 \mathrm{~g} \text { of buns } * \text { amount of buns }}{\mu g 5-\mathrm{CH}_{3}-\mathrm{H}_{4} \text { folate per } 100 \mathrm{~g} \text { of dough } * \text { amount of dough }}\right) * 100
$$

\subsection{Statistical analysis}

232 All results from the stability study of $\mathrm{L}-5-\mathrm{CH}_{3}-\mathrm{H}_{4}$ folate in capsules and buns were presented as means of three independent experiments, i.e., buns were prepared in three batches. One-way ANOVA was used to test the agreement in the recovery of $\mathrm{L}-5-\mathrm{CH}_{3}-\mathrm{H}_{4}$ folate between various samples within the day, and between different treatments. Tukey-Kramer test was used to examine the differences between the recovery of $\mathrm{L}-5-\mathrm{CH}_{3}-\mathrm{H}_{4}$ folate in the samples with free and two different types of encapsulated folate in capsules and buns. A p-value $\leq 0.05$ was classified as a significant difference. Statistical analyses were performed using JMP ${ }^{\circledR}$ Statistical Discovery software version 13.0 (SAS Institute Inc. Cary, NC, USA). The results were given as a mean \pm standard deviation (SD).

\section{Results and discussion}

\subsection{Optimization of biopolymer solutions and electrospraying process}

243 Processing conditions leading to stable Taylor cone, while maintaining high productivity, were needed to be investigated for the new biopolymer solutions with folate and Asc. Table 1 presents the overview of the experiments performed during the optimization of the electrospraying process

246 showing the productivity from each experiment. The processing conditions and biopolymer solution used in former studies, containing $15 \%$ glucose syrup and $4 \%$ pullulan, were optimized for encapsulation of fish oil (20\% load) (García-Moreno et al., 2018b). The recommendation for dietary intake of folate is $300 \mu \mathrm{g} /$ day $(\mathrm{NNR}, 2014)$. Therefore, a low amount of folate vitamer $\mathrm{L}_{-}-\mathrm{CH}_{3}-$ 
251 macronutrients should not affect the electrospraying process. Pullulan, which has excellent 252 spinnability properties (García-Moreno et al., 2018b), was added to enhance the stability of the 253 Taylor cone during electrospraying at increased flow rates. This increases the productivity of the 254 electrospraying process, which is required when producing encapsulates for food applications.

Table 1 Chronological overview of the experiments used in optimization of electrospraying process and the results for the productivity

During the optimization, the voltage and flow rate parameters were changed from the ones used by García-Moreno et al. (2018b), because of the instability of the process and formation of droplets during electrospraying. Even though previously optimized conditions ( $17 \mathrm{kV}$ and $0.007 \mathrm{~mL} / \mathrm{min})$ provided the highest productivity (Exp. 3 and 5), reduced flow rate $(0.006 \mathrm{~mL} / \mathrm{min})$ and increased 261 voltage $(20 \mathrm{kV})$ enabled a stable electrospraying process without dripping and droplets in the 262 collector. It should be noted that, despite the considerable difference in bioactive load (20\% fish oil 263 vs. $1 \%$ folate), the optimum processing conditions slightly varied. This indicates that the 264 electrosprayability of the solutions tested is mainly controlled by the concentration and molecular 265 weight of the biopolymers used.

Table 1 also shows that the addition of Tween-20 enhanced productivity, as observed when comparing Exp. 2 and 3, or 4 and 5. Tween-20 reduced the surface tension of the biopolymer 268 solution, which implies the use of low voltages to eject the jet from the Taylor cone, leading to a 269 more stable electrospraying process (e.g., less dripping) (García-Moreno et al., 2017). As expected, 270 the addition of Asc also led to higher productivity due to an increase in the solid content (Exp. 8 and 2719 in Table 1). Finally, increasing the number of Microfluidizer passes from 3 to 5, which could 272 imply more severe breaking of polymer chains, and thus less polymer chain entanglements did have 273 a clear effect on productivity. For instance, productivity was increased for solutions without Asc 
when increasing the number of passes (exp. 7 and 9), whereas the opposite was observed for solutions with Asc (Exp. 8 and 10) (Table 1). New optimized conditions used for the production of capsules are shown in Fig. 2.

Figure 2 Scheme of the optimized electrospraying setup and conditions used in this study

\subsection{Morphology and distribution of the capsules}

Fig. 3 shows the morphology and particle size distribution of produced capsules. The overall capsule sizes ranged from $0.72 \pm 0.41 \mu \mathrm{m}$ for capsules without Asc to $0.55 \pm 0.34 \mu \mathrm{m}$ for capsules with Asc, which is in accordance to the previous study using the same biopolymers where $60-70 \%$ of the capsules were below $1 \mu \mathrm{m}$ (García-Moreno et al., 2018b). Particles evaluated after production had a small particle size and smooth and round shape (Fig. 3), enhanced with the addition of the surfactant Tween-20 (SOM, Fig. S2). Minor fibrils also occurred during electrospraying. Thus, an increased number of Microfluidizer passes (5x) was tested in order to break polymer chain entanglements and reduce fibrils formation. However, a minor occurrence of fibrils was still visible (SOM, Fig. S3), which suggests that no further disruption of biopolymer chains (e.g., pullulan) was carried out after 3 passes. The capsules produced by electrospraying had smaller sizes compared to spray-drying $(10-50 \mu \mathrm{m})$, which enables better incorporation and more homogeneous distribution in a food product (Kitts and Liu, 2015).

Figure 3 SEM images and particle size distribution of electrosprayed capsules containing $1 \%$ Tween-20 surfactant after 3 Microfluidizer passes: (a) Capsules - Asc, (b) Capsules + Asc produced at optimum processing conditions (flow rate $0.006 \mathrm{~mL} / \mathrm{min}$, voltage $20 \mathrm{kV}$ )

\subsection{Stability of $\mathrm{L}-5-\mathrm{CH}_{3}-\mathrm{H}_{4}$ folate-loaded electrosprayed capsules}


295 Recovery of $\mathrm{L}-5-\mathrm{CH}_{3}-\mathrm{H}_{4}$ folate from electrosprayed capsules was $98 \pm 6 \%(\mathrm{n}=5)$ and $97 \pm 5 \%(\mathrm{n}=5)$ in the Capsules $-A s c$ and + Asc, respectively. Recovery was calculated as the mean from 5 measurements from two separated batches for each biopolymer solution. Batch 1 was used for the stability study of the capsules, whereas batch 2 was used for the fortification of flour. Stability of produced capsules was tested during storage in the freezer $\left(-80^{\circ} \mathrm{C}\right)$, which indicated that keeping the capsules in the freezer does not affect the stability of capsules (e.g., morphological changes and recovery of $\mathrm{L}-5-\mathrm{CH}_{3}-\mathrm{H}_{4}$ folate) (data not shown). Fig. 4 shows the oxidative stability of $\mathrm{L}-5-\mathrm{CH}_{3}$ $\mathrm{H}_{4}$ folate in capsules during storage at room temperature in darkness. The use of Asc in the capsules did not significantly improve the recovery of $\mathrm{L}-5-\mathrm{CH}_{3}-\mathrm{H}_{4}$ folate. However, Capsules + Asc showed higher recovery between the days, as Capsules - Asc differed significantly between the days. From day 7 , recovery of free $\mathrm{L}-5-\mathrm{CH}_{3}-\mathrm{H}_{4}$ folate was significantly lower $(\mathrm{p} \leq 0.05)$ than the recovery of encapsulated $\mathrm{L}-5-\mathrm{CH}_{3}-\mathrm{H}_{4}$ folate, and an almost linear decrease was observed within the 21 days.

Figure 4 Recovery $(\%)$ of $5-\mathrm{CH}_{3}-\mathrm{H}_{4}$ folate, free and in electrosprayed capsules during 21 days 308 storage in darkness at room temperature $\left(22^{\circ} \mathrm{C}\right)$. Different letters $a b c$ indicate significant differences between different samples within a day, whereas $u x y z$ indicate significant differences within the samples analyzed on different days $(\mathrm{p} \leq 0.05)$.

The distribution of $\mathrm{L}-5-\mathrm{CH}_{3}-\mathrm{H}_{4}$ folate, free form, and capsules with or without Asc in flour is shown

313 in Table 2. Blending the free $\mathrm{L}-5-\mathrm{CH}_{3}-\mathrm{H}_{4}$ folate into the flour resulted in a more uniform 314 distribution, whereas the distribution in Capsules - Asc varied as indicated by high SD. 315 Furthermore, the concentration of measured 5- $\mathrm{CH}_{3}-\mathrm{H}_{4}$ folate in Capsules + Asc was significantly 316 lower $(\mathrm{p} \leq 0.05)$ than in the other two fortified flours. These results indicate that some oxidation 
during blending may have occurred and that it is possible that using mortar and pestle during the integration of capsules into flour destroyed some capsules.

Table 2 Distribution of free and encapsulated $\mathrm{L}-5-\mathrm{CH}_{3}-\mathrm{H}_{4}$ folate in flour prior to dough preparation

Figure 5 Retention (\%) of 5- $\mathrm{CH}_{3}-\mathrm{H}_{4}$ folate from buns enriched with $\mathrm{L}-5-\mathrm{CH}_{3}-\mathrm{H}_{4}$ folate, free or in capsules, during 9 days storage at room temperature $\left(22^{\circ} \mathrm{C}\right)$ in darkness. Non-enriched buns represent 5- $\mathrm{CH}_{3}-\mathrm{H}_{4}$ folate naturally occurring from the other ingredients in buns, whereas the other samples have added $\mathrm{L}-5-\mathrm{CH}_{3}-\mathrm{H}_{4}$ folate. Different letters $a b c$ indicate significant differences between different samples within the day, whereas $x y$ indicate significant difference within the same sample between different days $(\mathrm{p} \leq 0.05)$.

Fig. 5 presents the retention of $\mathrm{L}-5-\mathrm{CH}_{3}-\mathrm{H}_{4}$ folate in enriched buns during 9 days of storage at room temperature $\left(22^{\circ} \mathrm{C}\right)$. No significant difference was found in the control and the buns containing Capsules + Asc over 9 days of storage. The recovery of $\mathrm{L}-5-\mathrm{CH}_{3}-\mathrm{H}_{4}$ folate in Capsules - Asc was significantly different from $100 \%$, and it was equal to $93 \pm 0.3 \%$ after production, which indicates that part of $\mathrm{L}-5-\mathrm{CH}_{3}-\mathrm{H}_{4}$ folate oxidizes during the production. Electrospraying is a suitable substitute for the spray-drying method in terms of working with thermally sensitive compounds like folate. In contrast to our results, in spray-drying sodium ascorbate have shown a protective effect on the stability of $\mathrm{L}-5-\mathrm{CH}_{3}-\mathrm{H}_{4}$ folate in capsules using modified starch as a coating material by providing $>95 \%$ recovery during the production of the capsules (Kitts and Liu, 2015; Liu et al., 2013).

In general, the use of electrosprayed capsules did not show any protective effect on the $\mathrm{L}_{-}-\mathrm{CH}_{3}$ $337 \mathrm{H}_{4}$ folate when incorporated into buns. Many different research works have evaluated the potential 338 of microencapsulation for the protection of food bioactives. However, data about their incorporation into food systems are scarce, even though they are important for the evaluation of capsules' 
340 behavior under processing conditions. Encapsulation by electrospraying has already been proven to

341 stabilize bioactive ingredients, but just a few studies tested the effect of capsules incorporation into

342 a food matrix and how food processing influences the stability of the fortified product (Gómez-

343 Mascaraque et al., 2017; Hermund et al., 2019; Miguel et al., 2019). Liu et al. (2013) encapsulated

344 L-5- $\mathrm{CH}_{3}-\mathrm{H}_{4}$ folate by spray-drying and studied storage stability for 7 days. $>50 \%$ loss of free L-5-

$345 \mathrm{CH}_{3}-\mathrm{H}_{4}$ folate was reported after baking, and degradation pattern in the recovery of $\mathrm{L}-5-\mathrm{CH}_{3}-$

$346 \mathrm{H}_{4}$ folate was observed in pilot baking bread study between the days 3 and 7. Our results showed

347 high retention $(100 \%)$ of free $\mathrm{L}-5-\mathrm{CH}_{3}-\mathrm{H}_{4}$ folate, which was significantly higher than the retention

348 of the encapsulated form. The same observation was made by Kitts \& Liu (2015), who used long-

349 chain fatty acid stearate derived from soybean oil for coating material in encapsulation by spray-

350 drying. Both encapsulated $\mathrm{L}-5-\mathrm{CH}_{3}-\mathrm{H}_{4}$ folate and folic acid showed lower recovery than

351 corresponding free forms, which was explained by exceeded melting points of stearate and

352 destruction of the capsules that caused oxidation and degradation. Furthermore, Liu et al. (2012)

353 reported a protective effect of skim milk powder and soy milk powder if added to a solution of L-5-

$354 \mathrm{CH}_{3}-\mathrm{H}_{4}$ folate, which indicates that some antioxidative properties of the food matrix may occur. In

355 non-enriched buns, the retention of $5-\mathrm{CH}_{3}-\mathrm{H}_{4}$ folate was $50 \%$ following baking at $200^{\circ} \mathrm{C}$ for 7.5

356 minutes, evidencing the instability of the naturally occurring 5- $\mathrm{CH}_{3}-\mathrm{H}_{4}$ folate. Baked buns were

357 stored for 9 days, and no significant difference in $5-\mathrm{CH}_{3}-\mathrm{H}_{4}$ folate content was observed during this

358 period, which was considered as a limit after which they would not be consumed. The retention of

359 free $\mathrm{L}-5-\mathrm{CH}_{3}-\mathrm{H}_{4}$ folate added to buns significantly decreased from $100 \%$ to $88 \%(\mathrm{p} \leq 0.05)$, whereas

360 no significant difference was observed in the retention of encapsulated $\mathrm{L}-5-\mathrm{CH}_{3}-\mathrm{H}_{4}$ folate after 9

361 days of storage. However, a significant difference between retention of $\mathrm{L}-5-\mathrm{CH}_{3}-\mathrm{H}_{4}$ folate in two

362 types of capsules was observed between days 0 and 3, which could be connected to reduced

363 uniformity of the capsule dispersion in the flour in Capsules - Asc as shown in Table 2. As the 
stability of free $\mathrm{L}-5-\mathrm{CH}_{3}-\mathrm{H}_{4}$ folate started to decrease, there was no significant difference $(\mathrm{p} \leq 0.05)$ between the stability of buns containing free $\mathrm{L}-5-\mathrm{CH}_{3}-\mathrm{H}_{4}$ folate and capsules on day 9. The decrease in retention of free $\mathrm{L}-5-\mathrm{CH}_{3}-\mathrm{H}_{4}$ folate in buns followed the pattern similar to the one observed in the recovery of free $\mathrm{L}-5-\mathrm{CH}_{3}-\mathrm{H}_{4}$ folate that was equal to $88 \%$ after 7 days of storage (Fig. 4).

Even though electrospraying enabled higher recovery than spray-drying (98\% vs. 91\%), which supports the hypothesis that thermally labile compounds such as folate may be preserved better than if using spray-drying, no protective effect from encapsulation was observed during buns fortification. Further investigation in alternative food products with a longer shelf life is recommended in order to examine if these electrosprayed capsules would improve the stability of folate vitamers during processing. However, our results were in accordance with GómezMascaraque et al. (2017), who found no significant effect of electrosprayed encapsulates loaded with green tea extract when incorporated into biscuits. These findings emphasize the importance of the further step of incorporation of developed capsules to a real food system as their performance varies depending on numerous parameters, such as physical properties of fortified products, as well as production and processing conditions.

\section{Conclusions}

High oxidative stability of electrosprayed capsules loaded with L-5- $\mathrm{CH}_{3}-\mathrm{H}_{4}$ folate was obtained within 21 days, as no significant difference was observed on $\mathrm{L}-5-\mathrm{CH}_{3}-\mathrm{H}_{4}$ folate recovery during 382 storage, whereas a significant decrease of $40 \%$ was reported for the free $\mathrm{L}-5-\mathrm{CH}_{3}-\mathrm{H}_{4}$ folate. The use 383 of $1 \%$ ascorbic acid as an antioxidant did not show any effect on the stability of the produced 384 capsules. Buns were baked with the capsules and stored for 9 days, which showed no significant 385 difference in retention between enrichment with free and encapsulated $\mathrm{L}-5-\mathrm{CH}_{3}-\mathrm{H}_{4}$ folate. However, 386 non-enriched buns containing naturally occurring folate from buns' ingredients showed 
significantly lower retention of folates $(>50 \%)$ during processing. Results showed that food processing is a critical step in the preservation of bioactive compounds even when a protection technique such as encapsulation by electrospraying is applied. Therefore, the study may serve as a basis for further research.

\section{Declarations of interest}

The authors declare that the research was conducted in the absence of any commercial or financial relationships that could be considered as a potential conflict of interest.

\section{Acknowledgments}

This research was supported by the Technical University of Denmark and by Danish Veterinary and Food Administration.

\section{References}

Alborzi, S., Lim, L.-T., Kakuda, Y., 2013. Encapsulation of folic acid and its stability in sodium alginate-pectin-poly(ethylene oxide) electrospun fibres. J. Microencapsul. 30, 64-71. https://doi.org/10.3109/02652048.2012.696153

Bailey, L.B., Stover, P.J., Mcnulty, H., Fenech, M.F., Gregory, J.F., Mills, J.L., Pfeiffer, C.M., Fazili, Z., Zhang, M., Ueland, P.M., Molloy, A.M., Caudill, M.A., Shane, B., Berry, R.J., Bailey, R.L., Hausman, D.B., Raghavan, R., Raiten, D.J., 2015. Biomarkers of Nutrition for Development— Folate Review 1-5. J. Nutr. 145, 1636-1680. https://doi.org/10.3945/jn.114.206599

Bearak, J., Popinchalk, A., Alkema, L., Sedgh, G., 2018. Global, regional, and subregional trends in unintended pregnancy and its outcomes from 1990 to 2014: estimates from a Bayesian 
hierarchical model. Lancet Glob. Heal. 6, e380-e389. https://doi.org/10.1016/S2214109X(18)30029-9

Berry, R.J., Bailey, L., Mulinare, J., Bower, C., Dary, O., 2010. Fortification of flour with folic acid. Food Nutr. Bull. 31, S22-S35. https://doi.org/10.1136/bmj.323.7323.1198

Boerekamp, D.M.W., Andersen, M.L., Jacobsen, C., Chronakis, I.S., García-Moreno, P.J., 2019. Oxygen permeability and oxidative stability of fish oil-loaded electrosprayed capsules measured by Electron Spin Resonance: Effect of dextran and glucose syrup as main encapsulating materials. Food Chem. 287, 287-294. https://doi.org/10.1016/j.foodchem.2019.02.096

Busolo, M.A., Torres-Giner, S., Prieto, C., Lagaron, J.M., 2019. Electrospraying assisted by pressurized gas as an innovative high-throughput process for the microencapsulation and stabilization of docosahexaenoic acid-enriched fish oil in zein prolamine. Innov. Food Sci. Emerg. Technol. 51, 12-19. https://doi.org/10.1016/j.ifset.2018.04.007

Dias, M.I., Ferreira, I.C.F.R., Barreiro, M.F., 2015. Microencapsulation of bioactives for food applications. Food Funct. 6, 1035-1052. https://doi.org/10.1039/c4fo01175a

European Union, 2002. Directive 2002/46/EC of the European Parliament and of the Council of 10 June 2002 on the approximation of the laws of the Member States relating to food supplements. Off. J. Eur. Communities 183, 51-57. https://doi.org/10.1016/j.jclepro.2010.02.014

European Union, 2006. Regulation (EC) No 1925/2006 of the European Parliament and of the Council of 20 December 2006 on the addition of vitamins and minerals and of certain other substances to foods. Off. J. Eur. Union L404, 26-38. 
430 Food and Drug Administration, 1996. Food standards: Amendment of standards of identity for enriched grain products to require addition of folic acid. Fed. Regist. 61, 8781-8797.

García-Moreno, Pedro J, Mendes, A.C., Jacobsen, C., Chronakis, I.S., 2018a. Biopolymers for the Nano-microencapsulation of Bioactive Ingredients by Electrohydrodynamic Processing, in: Gutiérrez, T.J. (Ed.), Polymers for Food Applications. Springer International Publishing, Cham, pp. 447-479. https://doi.org/10.1007/978-3-319-94625-2_17

García-Moreno, P.J., Özdemir, N., Stephansen, K., Mateiu, R. V., Echegoyen, Y., Lagaron, J.M., Chronakis, I.S., Jacobsen, C., 2017. Development of carbohydrate-based nano-microstructures loaded with fish oil by using electrohydrodynamic processing. Food Hydrocoll. 69, 273-285. https://doi.org/10.1016/j.foodhyd.2017.02.013

García-Moreno, Pedro J., Pelayo, A., Yu, S., Busolo, M., Lagaron, J.M., Chronakis, I.S., Jacobsen, C., 2018b. Physicochemical characterization and oxidative stability of fish oil-loaded electrosprayed capsules: Combined use of whey protein and carbohydrates as wall materials. J. Food Eng. 231, 42-53. https://doi.org/10.1016/j.jfoodeng.2018.03.005

Garrett, G.S., Bailey, L.B., 2018. A public health approach for preventing neural tube defects: folic acid fortification and beyond. Ann. N. Y. Acad. Sci. 1414, 47-58. https://doi.org/10.1111/nyas.13579

Ghorani, B., Tucker, N., 2015. Fundamentals of electrospinning as a novel delivery vehicle for bioactive compounds in food nanotechnology. Food Hydrocoll. 51, 227-240. https://doi.org/10.1016/j.foodhyd.2015.05.024

Gómez-Mascaraque, L.G., Hernández-Rojas, M., Tarancón, P., Tenon, M., Feuillère, N., Vélez Ruiz, J.F., Fiszman, S., López-Rubio, A., 2017. Impact of microencapsulation within 
electrosprayed proteins on the formulation of green tea extract-enriched biscuits. LWT - Food

Green, T.J., Liu, Y., Dadgar, S., Li, W., Böhni, R., Kitts, D.D., 2013. Wheat rolls fortified with microencapsulated L-5-methyltetrahydrofolic acid or equimolar folic acid increase blood folate concentrations to a similar extent in healthy men and women. J. Nutr. 143, 867-871. https://doi.org/10.3945/jn.113.174268

Hermund, D., Jacobsen, C., Chronakis, I.S., Pelayo, A., Yu, S., Busolo, M., Lagaron, J.M., Rosa, J., Akoh, C.C., García-moreno, P.J., 2019. Stabilization of fish oil-loaded electrosprayed capsules with seaweed and commercial natural antioxidants : effect on the oxidative stability of capsuleenriched mayonnaise. Eur. J. Lipid Sci. Technol. 1-10. https://doi.org/10.1002/ejlt.201800396

Jacobsen, C., García-Moreno, P.J., Mendes, A.C., Mateiu, R. V., Chronakis, I.S., 2018. Use of electrohydrodynamic processing for encapsulation of sensitive bioactive compounds and applications in food. Annu. Rev. Food Sci. Technol. 9, 525-549.

Liu, Y., Green, T.J., Kitts, D.D., 2015. Stability of microencapsulated L-5-methyltetrahydrofolate in fortified noodles. Food Chem. 171, 206-211. https://doi.org/10.1016/j.foodchem.2014.08.129

Liu, Y., Green, T.J., Wong, P., Kitts, D.D., 2013. Microencapsulation of L-5-methyltetrahydrofolic acid with ascorbate improves stability in baked bread products. J. Agric. Food Chem. 61, 247254. https://doi.org/10.1021/jf304229b 
Liu, Y., Tomiuk, S., Rozoy, E., Simard, S., Bazinet, L., Green, T., Kitts, D.D., 2012. Thermal oxidation studies on reduced folate, L-5-methyltetrahydrofolic acid (L-5-MTHF) and strategies for stabilization using food matrices. J. Food Sci. 77, 236-243. https://doi.org/10.1111/j.17503841.2011.02561.x

Ložnjak, P., García-Salinas, C., Díaz de la Garza, R.I., Bysted, A., Jakobsen, J., 2019. The use of a plant enzyme for rapid and sensitive analysis of naturally-occurring folates in food by liquid chromatography-tandem mass spectrometry. J. Chromatogr. A 1594, 34-44. https://doi.org/10.1016/j.chroma.2019.02.037

Miguel, G.A., Jacobsen, C., Prieto, C., Kempen, P.J., Lagaron, J.M., Chronakis, I.S., GarcíaMoreno, P.J., 2019. Oxidative stability and physical properties of mayonnaise fortified with zein electrosprayed capsules loaded with fish oil. J. Food Eng. 263, 348-358. https://doi.org/10.1016/j.jfoodeng.2019.07.019

NNR, 2014. Nordic Nutrition Recommendations. Nord. Nutr. Recomm. 2012. Nord. Counc. Minist. https://doi.org/10.6027/Nord2014-002

Obeid, R., Holzgreve, W., Pietrzik, K., 2013. Is 5-methyltetrahydrofolate an alternative to folic acid for the prevention of neural tube defects? J. Perinat. Med. 41, 469-483. https://doi.org/10.1515/jpm-2012-0256

Obeid, R., Oexle, K., Rißmann, A., Pietrzik, K., Koletzko, B., 2016. Folate status and health: Challenges and opportunities. J. Perinat. Med. 44, 261-268. https://doi.org/10.1515/jpm-20140346

Pietrzik, K., Bailey, L., Shane, B., 2010. Folic acid and L-5-methyltetrahydrofolate: Comparison of clinical pharmacokinetics and pharmacodynamics. Clin. Pharmacokinet. 49, 535-548. 
496 Samaniego-Vaesken, M.L., Alonso-Aperte, E., Varela-Moreiras, G., 2017. Voluntary folic acid fortification levels and nutrient composition of food products from the Spanish market: A 2011-2015 update. Nutrients 9. https://doi.org/10.3390/nu9030234

499 Scaglione, F., Panzavolta, G., 2014. Folate, folic acid and 5-methyltetrahydrofolate are not the same thing. Xenobiotica 44, 480-488. https://doi.org/10.3109/00498254.2013.845705

501 Stolzenberg-Solomon, R.Z., Chang, S.-C., Leitzmann, M.F., Johnson, K.A., Johnson, C., Buys, S.S., Hoover, R.N., Ziegler, R.G., 2006. Folate intake, alcohol use, and postmenopausal breast cancer risk in the prostate, lung, colorectal, and ovarian cancer screening trial. Am. J. Clin. Nutr. 83, 895-904. https://doi.org/10.1093/ajcn/83.4.895

Tapia-Hernández, J.A., Rodríguez-Félix, F., Katouzian, I., 2017. 9 - Nanocapsule formation by electrospraying, Nanoencapsulation Technologies for the Food and Nutraceutical Industries. Elsevier Inc. https://doi.org/10.1016/B978-0-12-809436-5/00009-4 


\section{List of captions:}

Figure 1 The design of the storage experiment in buns. It included retention study during baking (1) and stability study during storage for $0,3,6$, and 9 days (2). Three replicates were sampled at each sampling point. *indicate dough samples sampled for the calculation of the retention $(n=3)$.

Figure 2 Scheme of the optimized electrospraying setup and conditions used in this study

Figure 3 SEM images and particle size distribution of electrosprayed capsules containing 1\% Tween20 surfactant after 3 Microfluidizer passes: (a) Capsules - Asc, (b) Capsules + Asc produced at optimum processing conditions (flow rate $0.006 \mathrm{~mL} / \mathrm{min}$, voltage $20 \mathrm{kV}$ )

Figure 4 Recovery (\%) of $\mathrm{L}-5-\mathrm{CH}_{3}-\mathrm{H}_{4}$ folate, free and in electrosprayed capsules during 21 days storage in darkness at room temperature $\left(22^{\circ} \mathrm{C}\right)$. Different letters $a b c$ indicate significant differences between different samples within a day, whereas uxyz indicate significant differences within the samples analyzed on different days $(\mathrm{p} \leq 0.05)$.

Figure 5 Retention (\%) of L-5- $\mathrm{CH}_{3}-\mathrm{H}_{4}$ folate from buns enriched with $\mathrm{L}-5-\mathrm{CH}_{3}-\mathrm{H}_{4}$ folate, free or in capsules, during 9 days storage at room temperature $\left(22^{\circ} \mathrm{C}\right)$ in darkness. Non-enriched buns represent $5-\mathrm{CH}_{3}-\mathrm{H}_{4}$ folate naturally occurring from the other ingredients in buns, whereas the other samples have added $\mathrm{L}-5-\mathrm{CH}_{3}-\mathrm{H}_{4}$ folate. Different letters $a b c$ indicate significant differences between different samples within the day, whereas $x y$ indicate significant difference within the same sample between different days $(\mathrm{p} \leq 0.05)$. 
Table 1 Chronological overview of the experiments used in optimization of electrospraying process and the results for the productivity

Table 2 Distribution of free and encapsulated $\mathrm{L}-5-\mathrm{CH}_{3}-\mathrm{H}_{4}$ folate in flour prior to dough preparation 
Table 1 Chronological overview of the experiments used in optimization of electrospraying process and the results for the productivity

\begin{tabular}{|c|c|c|c|c|c|c|c|}
\hline Exp. & Solutions & $\begin{array}{l}\text { Asc } \\
(1 \%)^{*}\end{array}$ & $\begin{array}{c}\text { Tween-20 } \\
(1 \%)^{* *}\end{array}$ & $\begin{array}{c}\mathrm{L}-5-\mathrm{CH}_{3}- \\
\mathrm{H}_{4} \text { folate } \\
(1 \%)^{*}\end{array}$ & $\begin{array}{c}\text { Voltage } \\
{[\mathrm{kV}]}\end{array}$ & $\begin{array}{l}\text { Flow rate } \\
{[\mathrm{mL} / \mathrm{min}]}\end{array}$ & $\begin{array}{c}\text { Productivity } \\
{[\mathrm{mg} / \mathrm{h}]}\end{array}$ \\
\hline$\overline{1}$ & $15 \%$ glucose syrup $+4 \%$ pullulan & + & - & - & 17 & 0.007 & 44.5 \\
\hline 2 & $15 \%$ glucose syrup $+4 \%$ pullulan & + & - & - & 16 & 0.007 & 0.9 \\
\hline 3 & $15 \%$ glucose syrup $+4 \%$ pullulan & + & + & - & 17 & 0.007 & 74.9 \\
\hline 4 & $15 \%$ glucose syrup $+4 \%$ pullulan & + & - & - & 16.5 & 0.007 & 29.7 \\
\hline 5 & $15 \%$ glucose syrup $+4 \%$ pullulan & + & + & - & 17 & 0.007 & 85.3 \\
\hline 6 & $15 \%$ glucose syrup $+4 \%$ pullulan & + & + & - & 20 & 0.006 & 63.1 \\
\hline 7 & $15 \%$ glucose syrup $+4 \%$ pullulan & - & + & + & 20 & 0.006 & 45.4 \\
\hline 8 & $15 \%$ glucose syrup $+4 \%$ pullulan & + & + & + & 20 & 0.006 & 73.9 \\
\hline $9^{\#}$ & $15 \%$ glucose syrup $+4 \%$ pullulan & - & + & + & 20 & 0.006 & 51.4 \\
\hline $10^{\#}$ & $15 \%$ glucose syrup $+4 \%$ pullulan & + & + & + & 20 & 0.006 & 55.9 \\
\hline
\end{tabular}

Exp., experiment; Asc, ascorbic acid; L-5- $\mathrm{CH}_{3}-\mathrm{H}_{4}$ folate, L-5-methyltetrahydrofolate.

* percentage of the compound in capsule

*** percentage of the compound in biopolymer solution

\#5 Microfluidizer passes 
Table 2 Distribution of free and encapsulated $\mathrm{L}-5-\mathrm{CH}_{3}-\mathrm{H}_{4}$ folate in flour prior to dough preparation

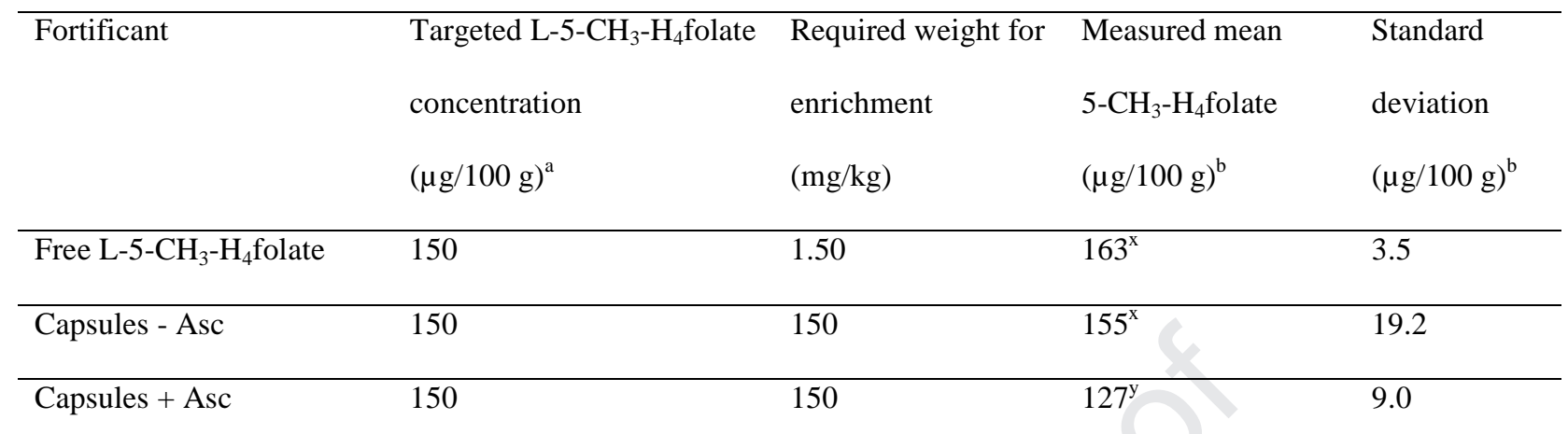

${ }^{\mathrm{a}} 150 \mu \mathrm{g}$ of $\mathrm{L}-5-\mathrm{CH}_{3}-\mathrm{H}_{4}$ folate/100 $\mathrm{g}$ of flour represent $1.5 \mathrm{mg} / \mathrm{kg}$ of flour fortification recommendation by FDA

${ }^{\mathrm{b}}$ Six determinations of each dry mix

Letters $x y$ indicate significant difference tested by Tukey-Kramer $(\mathrm{p} \leq 0.05)$. 


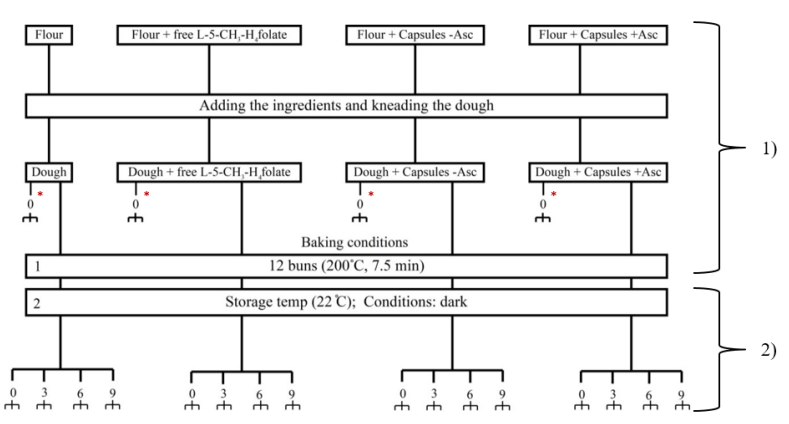




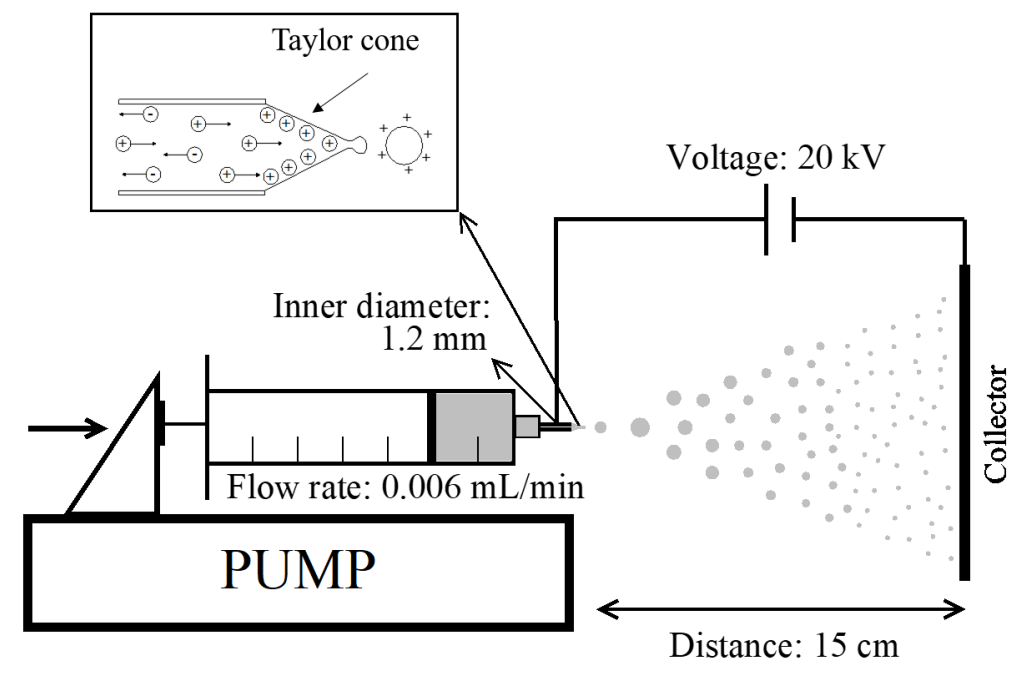



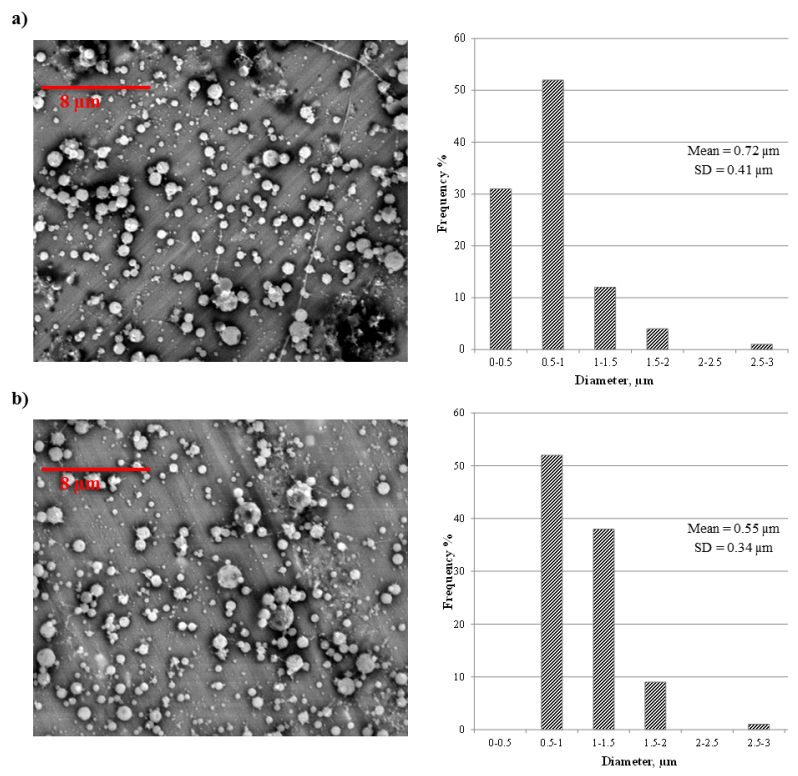


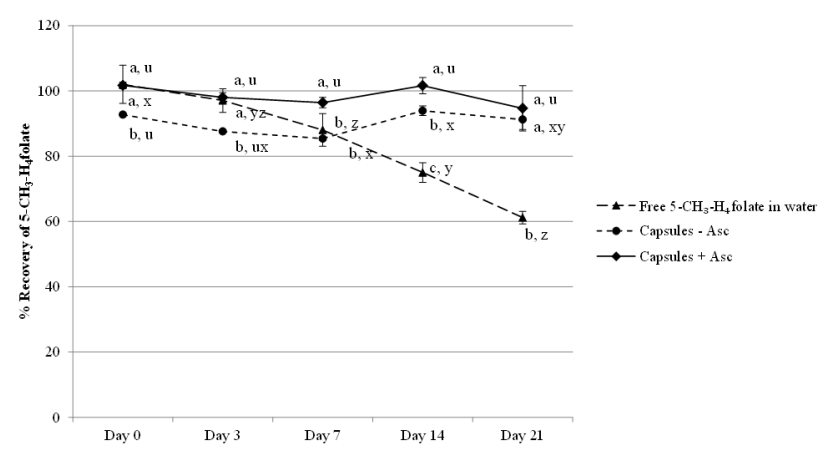




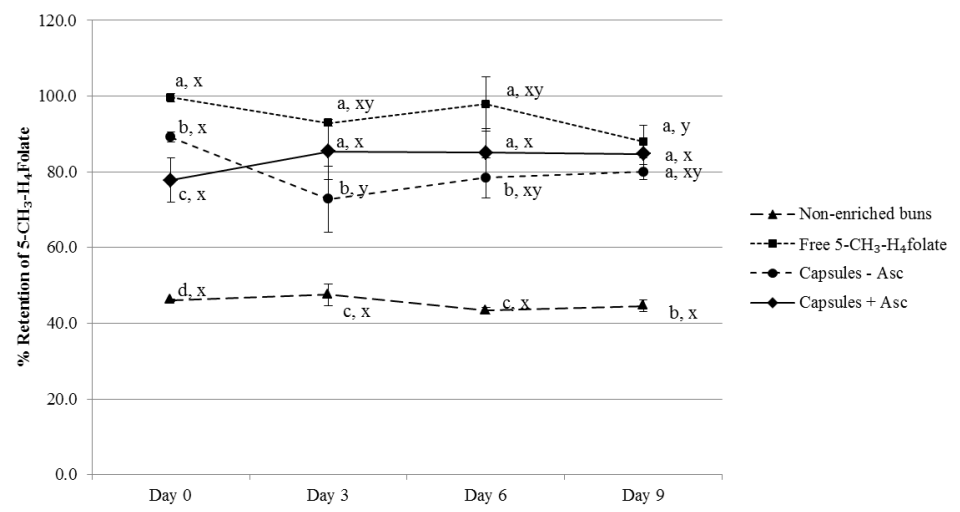




\section{Highlights:}

- Glucose-pullulan capsules containing $\mathrm{L}-5-\mathrm{CH}_{3}-\mathrm{H}_{4}$ folate were made by electrospraying

- Capsules are stable against oxidation during 21 days of storage in darkness at $22{ }^{\circ} \mathrm{C}$

- Ascorbic acid added to capsules does not improve the stability of L-5- $\mathrm{CH}_{3}-\mathrm{H}_{4}$ folate

- Encapsulation does not improve the retention of $\mathrm{L}-5-\mathrm{CH}_{3}-\mathrm{H}_{4}$ folate in buns 


\section{Author Contribution Statement:}

The authors responsibilities were as follows: Petra Ložnjak Švarc, Pedro J. García-Moreno, Ana C. Mendes, Elnaz Z. Fallahasghari and Jette Jakobsen contributed to the design of the study; Elnaz Z. Fallahasghari performed electrospraying optimization, and examined physical properties of the capsules; Petra Ložnjak Švarc conducted stability studies including folate analysis, data analysis and wrote the manuscript. All authors helped in interpretation of data. Petra Ložnjak Švarc, Pedro J. García-Moreno, Ana C. Mendes, and Jette Jakobsen read, reviewed and approved the final manuscript. 


\section{Declaration of interests}

$\bigotimes$ The authors declare that they have no known competing financial interests or personal relationships that could have appeared to influence the work reported in this paper.

$\square$ The authors declare the following financial interests/personal relationships which may be considered as potential competing interests: 